\title{
From The Flag State Duty For Inspections To The Remote Port State Control. The Necessity For Distant Controls
}

\author{
D. Kiltidou \\ Aristotle University of Thessaloniki, Thessaloniki, Greece
}

\begin{abstract}
Inspections are aiming at maritime safety. This paper describes the central role of flag states in controlling the vessels that are registered at their national register. However, the effectiveness of the inspections is mainly based on the Port State Control (PSC) inspections that are following the needs of the digital era introducing the remote controls.
\end{abstract}

\section{INTRODUCTION}

The inspection of ships is the milestone of seaworthiness. This is the reason why the control of the ships was firstly regulated by international conventions, introducing the strong connection that was necessary between the flag state and the ship. This connection didn't serve only in creating a legal environment within which the legal cases on board a ship could be resolved, but also served in creating a stable legal environment for the ship's control. However, the needs of the shipping community industry made it clear that this "genuine link" despite the fact it was necessary it wasn't sufficient enough to dominate the control procedure of ships. More precisely, the globalization and the phenomenon of open registries had as a consequence poor or mismanagement within the scope of cost cutting priorities and global competition. The states of open registries and especially those of flags of convenience, in several occasions, cannot exercise appropriate administrative control on ships that are registered at their national registries. As a result, the ships that are flying their flag do not respect international regulations as concerns maritime security and safety. In this reasoning, the procedure of Port State Control
("'PSC") was introduced in order to make the execution of controls more often and more objective.

Taking into account the fact that PSC is on the road of its progress, a new model of controlling appeared in order to affect PSC, the so-called remote inspections/controls that are already practiced by the flag states, classification societies and maritime management companies. The distant control of ships with the use of new technologies and modern communication couldn't leave aside the PSC. This paper stresses the importance of the remote inspections of PSC that became a necessity in the pandemic era of COVID-19 and should continue their existence in the field of PSC in the new digitalized era of maritime industry. Some states such as Liberia have already used the technology in order to response to the current health guidelines and restrictions due to COVID-19. Liberia was the first flag state that introduced the remote vessel closings, instrument recordation, remote class surveys and remote Annual Safety Inspection (ASI) program.

The paper is focused on two issues. It concentrates on the connection of inspections with the flag states, as the idea of controlling vessels' seaworthiness was initially orientated. Secondly, it analyses PSC from the 
scope of its digitalization, taking into account the real progress that has been done in flag states' inspections, following the paradigm of Liberia. These two directions are studied in order to emphasize that although the flag states' inspection has the first role in the control of the seaworthiness of the vessels that are registered at their national registers, the PSC has become the key for the global maritime safety. As a consequence, the shipping community should give prominence to the issue of the future effectiveness of the inspections that are exercised from port states by applying the modern communication and new technologies of our era. However, it is to be noted that although the modernization of PSC it is inevitably necessary, there are a lot of challenges to be faced.

\section{THE CONTROL OF SHIPS AS A FLAG STATE DUTY}

The inspection of ships is also a matter of jurisdiction over ships plying the seas. The flag state jurisdiction in inspecting the vessels flying their flag is the evidence of the developments of maritime community in order to respect safety at sea. More precisely, this connection between the flag state and the ship sets a legal framework under which the operation of the ship is governed. Furthermore, it must be mentioned that the flag of the ship plays an important role in the application of international law when the flag states have implemented international law into their national legal system (Brownlie, 1998; Tetley, 1993; Sigh, 1978; Lefrançois, 2010; Meyers, 1967). As a consequence, international community imposed the duty of flag state for inspections through international conventions, such as the Convention on High Seas 1958 ("HSC") and the United Nations Convention on law of the Sea 1982 ("UNCLOS").

\subsection{The Duties Of Flag State for Inspections Under UNCLOS}

Each state can determine the conditions under which a ship can fly its flag. But its jurisdiction does not stop at this point. The flag state has many duties regarding the effective jurisdiction and control of ship that is registered at its national ship register. More precisely, the article 94 of the UNCLOS elucidates the duties of the flag states in a separate article. The provisions of the article are based on the article 5 and 10 of the Convention HSC. The final form of article 94, and especially articles $2-5$, were based on a working paper on the high seas stating precisely the obligations of the flag state (Belgium, Denmark, France, Ireland, Italy, Luxembourg, Netherlands and United Kingdom: Working paper on High Seas, 12 August 1974, UNCLOS III, official records, III). The article 94 of UNCLOS lists explicitly flag state requirements (Franckx, 1997; Kasoulides, 1989). Moreover, article 94 should be read in conjunction with the provisions of the article 92 of the same convention that stresses that ships shall sail under the flag of one state only and, shall be subject to its exclusive jurisdiction on the high seas. The scope of the article, it can be said that it is to secure more effective implementation of the duties of the flag state and not to establish criteria by reference to which the validity of registration of ships can be challenged by other states.

The flag state exercises its jurisdiction and controls in administrative, social and technical issues, as it is described in par. 1. of the article. This paragraph of the article has been taken from article 5 of HSC where it was adopted in order to strengthen the genuine link with regard to the nationality of the ship and in order to give further indication to the link between the flag state and ships flying its flag. However, at this point it must be stressed that although all the above mentioned matters such as administrative, social and technical are strongly linked to the state were the ship is registered, in article 94 there is absence of a link between them and the genuine link provision of article 91, par. 1. This view increases the difficulty of arguing that a failure by the flag state to perform its duties could rise evidence of the absence of genuine link, as it was stated by Brown (Brown, 1994). Otherwise the failure of a flag state to accomplish with the requirements of article 94 would render national registration a nullity. The article 1 of the United Nations Convention on the Registration of Ships 1986 ("CRS 1986") precise the connection between the flag state and the ship as it mentions that the effective exercise of the jurisdiction and control over ships concerns the identification and accountability of the ship owners and operators as well as the administrative, technical, social and economic matters. At this moment this Convention is not into force, as only 14 countries have become signatory parties it. In par. 2 of the same article the duties of the flag state are more concrete and in these are included the registration of a ship at one country's ship register containing the names and "particulars" of ships flying its flag. Furthermore, the master, the crew and the officers of the ship have to respect the law of the country of the ship register and it can be added that the law of ship's register is applicable to all person on board a ship, such as passengers (Hosanee, 2009). In par. 3 of the article there are mentioned, not restrictively but inter alia the measures that the flag state should take necessarily to ensure the safety at sea concerning the construction, equipment and seaworthiness of ships, the manning of ships, labour conditions and the training of crews, taking into account the applicable international instruments, the use of signals, the maintenance of communications and the prevention of collisions. The seaworthiness as it is prescribed in par. 3 is supplemented by article 219 which concerns vessels' obligation to be in seaworthy condition in order to avoid marine pollution. In par. 4 it is prescribed that each ship, before registration and thereafter at appropriate intervals, is surveyed by a qualified surveyor of ships for the safe navigation of ship. Also, flag state's measures shall ensure that the qualifications of the master and the crew are appropriate and that these persons are fully conversant with and required to observe the applicable international regulations concerning the safety of life at sea, the prevention of collisions, the prevention, reduction and control of marine pollution, and the maintenance of communications by radio. Par. 5 addresses the obligation of the flag state to take any possible steps in order to ensure the observance of the ship. The flag state must take all the measures in order to conform to generally accepted regulations, 
practices and procedures relating to the safety of life at sea, the prevention of collisions and marine pollution and the maintenance of radio communications. According to par. 6 a flag state must take all the necessary remedies when a state has clear grounds to believe that proper jurisdiction and control with respect to a ship have not been exercised and reported the facts. In other words, par. 6 supplements par. 1 because it sets the obligation of the flag state to exercise its jurisdiction and control over ships flying its flag (Hosanee, 2009). Finally, in par. 7 is stressed the duty of the flag state to set an enquiry when a marine casualty or incident of navigation happens to a ship flying its flag on high seas. This paragraph mainly cultivates the idea of cooperation between nations in order to clarify incidents which are taking place on high seas. In this vein, IMO encouraged cooperation and recognition of mutual interests of states in marine casualties and incidents' investigation through resolutions and conventions.

\section{THE EMPOWERMENT OF PORT STATE CONTROL}

The flag state control on vessels that are registered on the national register is an inevitable duty of the flag state (Brownlie, 1998). Nevertheless, many flag states are not able or they are reluctant to practice controls on their ships or there is a serious failure on the part of many flag states to implement and enforce international standards. Whereas, henceforth the global community tried to find out a more effective way of controls on ships regarding maritime safety, the protection of maritime environment and the respect of decent shipboard living and working conditions, as it is clearly stated in the Directive $95 / 21 /$ EC. As it was clearly said by scholars, the first line of defense of eliminating substandard vessels is the flag state and the second line is the PSC (Knapp, S and Franses, P.H., 2007). However, as it will be analyzed below, it is evident that there is need for PSC inspections to improve the inspection efficiency and accuracy. PSC is becoming the essential and appropriate guardian of maritime safety. Last but not least, the digitalization of PSC was found in the agenda of international organizations and flag states far before the appearance of the pandemic phenomenon of COVID-19. However, although it started as an urgent necessity in this period of time, it is going to stay in maritime industry.

\subsection{A General Approach Of Port State Control}

In 1982 fourteen European states conceived the first regional agreement on inspections system with Paris Memorandum of Understanding on PSC (Paris MOU) in order to stem the proliferation of substandard vessels across European waters (Graziano, 2018). It is also to be noted that Paris MOU in which 27 participating maritime authorities agree to implement a harmonized system of PSC.

Since the Hague Memorandum in 1978, PSC is the basic global strategy for fighting substandard shipping. Furthermore it improved the coordinated ship safety inspections regarding safety of ships and the crew and the protection of maritime environment and living and working conditions. The evident role of PSC was that many flag states couldn't fulfill their obligation on their vessels (Ozçayir, 2004, 2009; Anderson, 2002). In Europe, it seems to be the most efficient and reliable regional agreement, although there are a lot of differences at the inspector and member state level.

At European level, relevant Directives aimed to help drastically to reduce substandard vessels in the waters of jurisdiction of member states. The European Directives aimed at ensuring a harmonized approach to the effective enforcement of international standards by member states when performing control to all the ships calling at their ports. In that respect, Directive 1995/21/EC stressed the increasing compliance with international and relevant community legislation on maritime safety, protection of the marine environment and living and working conditions on board a ship of all flags. Moreover, it focuses on establishing common criteria for control of ships by the Port State and harmonizing the procedures of detention and inspection taking into account Paris MOU. This Directive has been replaced by the Directive 2009/16/EC (article 1) as amended by the Directive 2013/38/EU. More precisely, Directive 2009/16/EC introduces the SafeseaNet inspection database as it is described by Directive 2002/59/EC. Moreover, Directive 2009/16/EC and Directive 2013/38/EU improved the first Directive in general and especially Directive 2013/38/EU enforced the application of the Maritime Labour Convention 2006 (MLC 2006) during PSC procedure.

Moreover, it is also to be noted that IMO's initiative enforced the contribution of regional cooperations. Many of the IMO's conventions contain provisions for ships to be inspected when they approach foreign ports in order to ensure that they comply with IMO requirements. With the Resolution A.682(17) the Organization promoted regional cooperations in the control of ships in order to render the inspections more coordinated and effective. The initiative of IMO concluded to 9 regional MOUs on PSC that have been signed. These MOUs are: Europe and the north Atlantic (Paris MoU); Asia and the Pacific (Tokyo MoU); Latin America (Acuerdo de Viña del Mar); Caribbean (Caribbean MoU); West and Central Africa (Abuja MoU); the Black Sea region (Black Sea MoU); the Mediterranean (Mediterranean $\mathrm{MoU}$ ); the Indian Ocean (Indian Ocean MoU); and the Riyadh MoU. The United States Coast Guard maintain the tenth PSC regime.

\section{THE REMOTE PSC AS A SOLUTION}

It seems that a new era of challenges has started. In the shadow of the last pandemic, such as the long period of COVID-19, a new model of flag states' inspections was formed on ships in order to control ships' safety (for example, Liberia exercised distant inspections). It can be said that the distant controls will overwhelm the difficulties of inspections with physical presence, however careful steps must be taken in order facilitate and ameliorate these controls. In this vein, it will be described below why the 
digitalization of our era could be useful in inspections through PSC.

\subsection{The Problems Of The Port State Control That Create The Necessity For Remote Inspections}

The port state control does not appear any genuineness of a link between the flag state and the vessel. Instead, it is practiced by port states to any vessel that enter them no matter of their flag. In other words, PSC is the international regime of inspection of foreign ships that enter the port state and aims to ensure that the inspected vessels are compliant with international conventions. Its success is found upon its distinction from the patchy implementation of flag state control as it is regulated by international conventions and guidelines (Gauci, 2017). The deficiencies of the way that inspections are conducted have raised complaints from the part of ship owners as they were represented in Intertanko and ICS (Knudsen and Hassler, 2010). Although the MOU 1982 has set the harmonization of standards on the inspection of vessels within the region where MOU was established this goal faced several problems. The main reason of developing PSC was the need about sharing information on safety records of vessels and to avoid the inspection of a vessel at every port within a region. However, these harmonized rules didn't face the same practice as the discrepancies in every state could affect the performance of the controls (Ozçayir, 2004, 2009). Also, insufficient funds for the exercise of PSC and lack of appropriate personnel should be taken into account, for example in some states inspections are subject to budgetary restraints.

Moreover, inspections are exercised by national inspectors who are supposed to be qualified according to international standards. However, in EU level, for example the problem of different inspection approaches is evident within each member state creating a substantial heterogeneity even between ports of the same country (Graziano, 2008). Although international standards are setting the qualification of inspectors, differences among MOU states concerning inspectors' knowledge, have raised doubts encompassing the PSC system as a whole (Graziano, 2008). Moreover, a set of skills is necessary by the part of inspectors and the crew. This does not mean that the crew must be qualified in order to exercise a control but only to be qualified in a manner that can ameliorate the control and state any false evaluation during the control. Despite the fact that important steps have been made to this direction maritime companies do not qualify appropriately their crews and as a result inspectors' qualifications show deficiencies. Another issue of PSC is that the number of inspectors has been strongly connected with the decision of the inspectors to detain a ship (Graziano, 2007). As a consequence, the inspections that are controlled by shore and by digital systems, provide a safe decision regarding to the detention of ships.

Furthermore, some PSC are dangerous and for this reason are exercised in deficient way or are not able to be exercised at all. In line with this, remote PSC could be a safer manner of practicing controls in a safer environment. The subjectivity of the inspectors and their different level of education still create problems at the result of the inspections.

\subsection{Thoughts On The Advantages And The Challenges Of The Remote PSC}

In the modern era of digitalization remote inspections are exercised in all the kinds of controls and inspections on ships, by classification societies, maritime companies, flag states (such as Liberia) and by port states. However, careful steps should be taken in order to strengthen inspections and transfigure the disadvantages of the on-site inspections with physical appearance of inspectors to advantages of remote inspections. At this point, it is essential to be noted that the IMO tried first through the code International Safety Management Code for the safe Operation of Ships and for Pollution Prevention ("ISM Code") to ensure maritime safety and security by creating special obligations to shipping companies. The Safety Management System ("SMS") which is part of ISM Code, consists a system ensuring the maritime safety on board a ship and it is installed by the company providing shore-based support. Also, it creates direct responsibility on shore side management. However, although maritime safety is ensured within the framework of the shipping company that operates the vessels, it is important to study further than the distant and shore-based control and support from the company, and focus on more objective inspections that are exercised by the port state.

Firstly, it is necessary to be stressed that in the case of remote PSC new operational functions will be possible, such as the web-based video communication that offers the ability to liaise the inspector with the ship's crew. Moreover, the remote PSC surveys can minimize the subjectivity of the inspections' surveys, provided that the surveys are transparent and liable to be reviewed from the ship owner, the crew, the flag state and the classification society. As a consequence, all the mentioned participating parties could participate in the procedure, answer immediately to any question of the inspector or correct directly any deficiency that will be probably found on the vessel. This participation could ensure the transparency of the procedure, offer a more simple and comprehensive way of exercising the PSC and lead to more safe and accurate conclusions. However, it should be underlined that there is a need for a regulatory framework for remote controls with the initiative of international organizations and the participation of port states and flag states. Moreover, it could be discussed whether robots could exercise the inspections instead of humans. In this case, it could be supported that artificial intelligence and appropriate software could take the place of human competences and conception. Nevertheless, the replacement of inspectors with robots must be done carefully and be scheduled in a way that software takes into account different circumstances that are happening on board a ship. Furthermore, a comprehensive remote inspection PSC checklist and procedure should be planned by port states in order to ensure the framework of the procedures of PSC.

Furthermore, measures of digital secure also must be taken so that the risk assessment in PSC will be 
minimized. In this context, databases of PSC could be easily used during the inspections so that the risk assessment from the part of the inspector will be minimized. The white list has also set a global instrument of information regarding the application of international conventions concerning maritime safety, decent living and working conditions on board a ship and the protection of maritime environment. Hence, it could be said that in the case of a remote PSC it will be easier to have access in the inspection database, such as the SafeseaNet or the white/grey/black list which is published in the Paris MOU annual report and exercise the inspection at the same time of regarding at the information provided by these lists.

Finally, in remote PSC the deficiencies of the inspections could be easily detected as far as all the information of an inspection can be controlled at the real time of the inspection. In this vein, it could be stressed that probable deficiencies of the inspections could be corrected at the real time of the inspection. Moreover, with distant inspections it is easy to construct combined databases that will lead to the harmonization of the PSC authorities' databases. Nevertheless, despite the advantages of remote PSC, the international maritime community should focus on maintaining some advantages of PSC with physical presence such as the consultative role of the inspector during the inspection.

\section{CONCLUSION}

The control of the ships is firstly a duty of the flag state. However, PSC seems to be the solution to the ambivalent surveys and ensure maritime safety. Despite the fact that there are many deficiencies in the PSC procedure such as the lack of uniform application of inspection standards, lack of appropriate personnel, problems due to subjective opinion of PSC officers in case of vessel detention, differences in training of inspectors, asymmetrical inspecting behavior, motivated the international shipping community to look for effective efforts in order to correct the deficiencies of PSC. Recently, urgent situations such as COVID-19 imposed the necessity of remote controls at the level of classification societies' control and flag states' control. In this vein, it could be sustained that the key to the PSC fulfillment is the application of modern technologies on PSC procedures. For this reason, international maritime community should enhance the ways of practicing PSC by distance and with the help of digitalization. For this purpose, the relevant international organizations and all the parties of shipping industry should attempt to regulate the remote PSC procedures at international level. For example, it could be supported that the participation of more parties could ensure the objectivity of controls and better results on maritime safety because multidisciplinary teams that exercise the PSC can lead to more structured inspection procedures.

From one side it seems that the deficiencies in PSC procedures overwhelm the aims of this international regime, and from the other side it appears that the regression in control procedures is a part of the past and that new technologies and computing will demand its place in the inspections' procedure. It could be noted that the era of smart ships and smart ports is demanding for "smart controls" too. Above all, it must be noted that remote PSC became a necessity and the shipping world cannot ignore it but focus on the better way of exercising these controls under an internationally accepted legal framework that will be based on the experience of the past and the challenges of the future.

\section{REFERENCES}

[1] Anderson D. (2002). The effect of Port State Control on substandard shipping. Maritime Studies 125. 20-25

[2] Brown E.D. (1994). The international law of the sea. Vol. 1. Dartmouth. Aldershot

[3] Brownlie I. (1998). Principles of public international law. 5 th ed. Claredon Press. Oxford

[4] CMI (1987). Comité Maritime International, Conventions Internationales de Droit droit maritime. Textes. Brussels

[5] Dinh N.Q., Dailler P., Pellet A. (2009). Droit international public. 7th ed. LGDJ. Paris

[6] Franckx E. (1997). Belgium and the law of the sea, in Treves T. and Pineschi L.. The law of the sea, The european Union and its member states. Martinus Nijhoff Publishers. The Hague/boston/London

[7] Graziano A., Schröder-Hinrichs J.-U., Ölcer A.I. (2017). After 40 years of regional and coordinated ship safety inspections: Destionations reached or new point of departure? Ocean Engineering 143. 217-226. Available at http://dx.doi.org/10.1016/j.oceaneng.2017.06.050

[8] Herman L. (1978). Flags of convenience - new dimensions to an ole problem. McGill Law Journal. vol. 24(1). 1-30

[9] Hosanee N. (2009). A critical analysis of flag state duties as laid down under article 94 of the 1982 United Nations convention on the law of the sea. Division for ocean affairs and the law of the sea office legal affairs. The United Nations. New York

[10] Gauci G.M., Aquilina K. (2017). The legal fiction of a genuine link as a requirement for the grant of nationality to ships and humans-The triumph of formality over substance?. ICLR. 17(1). 167-191.

[11] Kasoulides G. (1989). The 1986 United Nations convention on the conditions for registration of vessels and the question of open registry. Ocean Development \& International Law. 20(6). 543-576

[12] Knapp S. and Franses P.H. (2007). A global view on PSC: econometric analysis of the differences across port state control regimes, Maritime Policy \& Management 34(5). 453-482

[13] Knudsen O. and Hassler B. (2010). IMO legislation and its implementation: Accident risk, vessel deficiencies and national administrative practices. Marine Policy. doi:10.1016/j.marpol.2010.09.006

[14] Lefrançois A. (2010), contrôle technique et social par l' État du port: un enjeu pour $1^{\prime}$ Union Européenne. ADMO 2010. 355-392

[15] Meyers H. (1967). The nationality of ships. Martinus Nijhof Publishers. The Hague/boston/London

[16] McConnell M.L. (1985). '...Darkening Confusion Mounted Upon Darkening Confusion: The Search for the Elusive Genuine Link', Journal of Maritime Law and Commerce 16. 381-385

[17] Nordquist M.H., Grandy NR., Nandan S.N., Rosenne S. (Eds.) (1995). United Nations Convention on the Law of the Sea 1982: A Commentary. Vol. III, Martinus Nijhof, Leiden istep?

[18] Özçayir O. (2004). Port State Control. 2nd ed.. LLP. London 
[19] Özçayir O. (2009). The use of Port State Control in maritime industry and application of the Paris MOU. Ocean Coast. Law J. 14(2), 201-239

[20] Singh N. (1978). Maritime flag and international law. A.W. Sijthhoff international publishing. Leiden

[21] Tetley W. (1993). The law of the flag, "flag shopping" and the choice of law. Tulane Maritime Law Journal $17(2), 139-184$

[22] UNCLOS III, official records, 12 August 1974, Belgium, Denmark, France, Ireland, Italy, Luxembourg, Netherlands and United Kingdom: Working paper on High Seas

[23] United Nations, treaty collections, United Nations Convetnion on Conditions for Registration of Ships. Available at https://treaties.un.org/Pages/ViewDetails.aspx?src=TRE ATY\&mtdsg_no=XII-7\&chapter=12\&clang=_en 